\title{
SPATIAL VARIATION OF CHEMICAL ATTRIBUTES IN ARCHAEOLOGICAL DARK EARTH UNDER COCOA CULTIVATION IN WESTERN AMAZON
}

\author{
VARIAÇÃO ESPACIAL DE ATRIBUTOS QUÍMICOS EM TERRA PRETA \\ ARQUEOLÓGICA SOB CULTIVO DE CACAU NA AMAZONIA OCIDENTAL
}

\begin{abstract}
Roneres Deniz BARBOSA'; Alan Ferreira Leite de LIMA²; Emily Lira SIMÕES ${ }^{3}$; Elilson Gomes de BRITO FILHO ${ }^{4}$; Milton César Costa CAMPOS ${ }^{5}$; José Maurício da CUNHA ${ }^{5}$; Bruno Campos MANTOVANELLI ${ }^{5}$, Douglas Marcelo Pinheiro da SILVA ${ }^{5}$; Fernando Gomes de SOUZA ${ }^{6}$

1. Estudante de mestrado, Instituto Nacional de Pesquisas da Amazônia - INPA, Manaus, AM, Brasil, roneresbarbosa@gmail.com; 2. Estudante de mestrado, Universidade Federal do Amazonas - UFAM, Manaus, AM, Brasil; 3. Engenheira agrônomo, Universidade

Federal do Amazonas - UFAM, Humaitá, AM, Brasil; 4. Estudante de Graduação, Universidade Federal do Amazonas - UFAM, Humaitá, AM, Brasil; 5. Docente, Universidade Federal do Amazonas - UFAM, Humaitá, AM, Brasil; 6. Docente, Instituto Federal de Educação, Ciência e Tecnologia de Rondônia - IFRO, Colorado do Oeste, RO, Brasil.
\end{abstract}

\begin{abstract}
Archeological Dark Earths (ADEs) are fertility soils that are notoriously superior to the vast majority of soils typical of the Amazon region. The study on ADEs has intensified due to the good characteristics presented by these soils, such as high concentration of nutrients (phosphorus, calcium, magnesium). In this sense, the aim of this study was to evaluate the spatial distribution of soil chemical attributes in an area of black archeological earth soil under cocoa cultivation in the municipality of Apuí (AM). The mapping of a $42 \times 88 \mathrm{~m}$ mesh, with irregular spacing of $6 \times 8 \mathrm{~m}$, totaling 88 points, was carried out, and then soil samples were collected at depths of 0.0-0.05; 0.05-0.10; (pH, O.C, Sto C, (H+Al), P, K, Ca, Mg, SB, CEC and V\%). Data were analyzed using descriptive and geostatistical statistics techniques. The mean and median values were adjusted to the near values, indicating normal distribution, while the soil chemical attributes were adjusted to the spherical and exponential semivariograms models. The majority of the attributes presented coefficient of variation (CV) between 12.1 and $60 \%$, characterized as average variability, the variables in the study presented different ranges and most of them had a strong spatial dependence. The geostatistical techniques used allowed the adjustments of the theoretical models that best represented the experimental semivariance, thus enabling the construction of thematic maps of the spatial distribution of the values of the attributes of the studied area.
\end{abstract}

KEYWORDS: Soil attributes. Descriptive statistics. Geostatistics. Apuí. Spatial distribution.

\section{INTRODUCTION}

The Amazon region is characterized by the enormous diversity of life, both plant and animal, as well as human societies (PESSOA JUNIOR et al., 2012). Most of the arable soils of this region are acidic, with low cation exchange capacity (CEC) and low natural fertility. This region is characterized by its advanced stage of weathering, presenting physical characteristics suitable for agricultural use, however with strong nutritional limitations (LIMA et al., 2006, CUNHA et al., 2007).

In contrast, there are records of soil areas that have been affected by pre-historic man, which have a dark color, remains of archeological materials (ceramic fragments and lithic artifacts) and high $\mathrm{Ca}^{2+}, \mathrm{Mg}^{2+}, \mathrm{Zn}, \mathrm{Mn}, \mathrm{P}$, and the black soil of this layer is commonly known as Archeological
Dark Earths (ADEs), "Terra Preta de Indio" (TPI) or Black Earth (BE) (KERN and KÄMPF, 1989).

According to German (2003), these areas of $\mathrm{ADE}$ are found adjacent to water courses, occupying floodplain areas, marginal rises, with expansion ranging from one to hundreds of hectares, along rivers and inter-rivers. These potentially agricultural areas are being extensively explored in the Amazonian environment, but inadequate use and management can cause undesirable changes in the natural ecosystem, leading to soil degradation (CAMPOS et al., 2012). Thus, the studies of the transformations resulting from the use and management of the soils is of great importance for the adoption of more compatible systems for each type of evaluated area (ROZANE et al., 2010).

As regards chemical properties, Archeological Dark Earths have characteristics that 
supplant the natural conditions of the adjacent soils of the Amazon region that typically present low retention of nutrients due to the low concentration of organic material incorporated in the soil as the occurrence of the natural fields that present high aluminum concentration, resulting in low values and $\mathrm{pH}$, according to Mantovanelli et al. (2016); Viana et al. (2016).

When trying to know the variability in the soil, difficulties are encountered and this is due to two factors: firstly because of the great territorial extension of the Amazon region and few researchers, the number of samples in the spatial variability studies, besides the lack of knowledge and choice of a pattern in the use of sample spacing (OLIVEIRA et al., 2015). Currently one of the tools to verify the existence of the variability in the environment is geostatistics, it has allowed to analyze characteristics and their random and spatial aspects, creating an image of the variability of characters, identifying the degree of spatial dependence and providing information that allows subsidizing the study of the phenomena to be analyzed (SILVA NETO et al., 2012).

In this sense, the study of spatial dependence presents itself as an alternative not only to reduce the effects of soil variation on crop production, but also to estimate responses of soil properties due to certain management practices, besides allowing the reduction of the effects of horizontal and vertical soil variability, in many cases, may even influence the interpretation of its effects (Souza et al., 2004). In addition, a number of studies have demonstrated that the chemical attributes of the soil present intense spatial dependence, verified by geostatistical analysis (CAMPOS et al., 2007; ZANÃO JÚNIOR et al., 2007; MARQUES JÚNIOR et al., 2008; LIMA et al., 2013).

Therefore, the objective of this work was to evaluate the spatial variation of chemical attributes in Archeological Dark Earth area under cocoa cultivation in the Western Amazon.

\section{MATERIAL AND METHODS}

\section{Characterization of the physical environment}

The study area is located in the municipality of Apuí, Amazonas, Brazil, located along the Transamazônica highway (BR-230), under the geographic coordinates of $7^{\circ} 12^{\prime} 05$ 'S and 59 $39^{\prime}$ 37" W. According to Köppen classification the climate of the region belongs to group A (Tropical Rainy Weather) and climatic type Am (monsoon rainfall), presenting a dry period of short duration. The rainfall is limited by the isoietas of 2,250 and $2,750 \mathrm{~mm}$, with rainy period beginning in October and extending until June. Annual mean temperatures range from $25{ }^{\circ} \mathrm{C}$ to $27{ }^{\circ} \mathrm{C}$ and relative moisture between 85 and $90 \%$ (Figure 1).

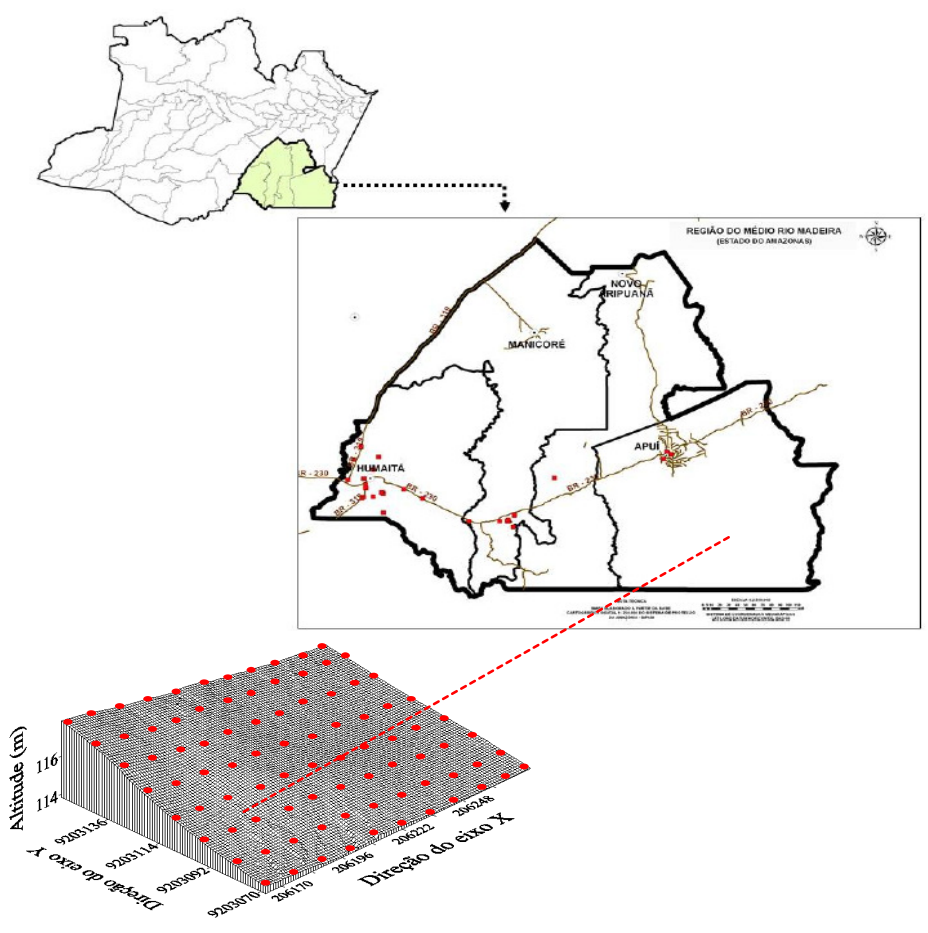

Figure 1. Map of the southern region of the Amazon. Source: Adapted from Santos (2011). 
The geology of the region presents sandstones of the beneficent formation, covered by clay pack of the tertiary. In relation to the soils present in the municipality, the following classes predominate: Ultisols and Oxisols, and the soil of the study area was classified as Argissolo Amarelo the according to Embrapa (2013) and Typic Haplohumult the according to Soil Taxonomy (SOIL SURVEY STAFF, 2010).

The characteristic vegetation of this region is the Dense Tropical Forest consisting of densified and multi-layered trees between 20 and 50 meters in height. According to Campos (2012), the predominant landscapes of this region are the natural fields, natural fields/forests. The BAE area has been cultivated for fourteen years, during the first six years it has been used to cultivate rice, maize, beans and watermelon, and the cocoa culture that has remained until the present study has been inserted.

\section{Soil sampling and chemical measurements}

The survey was carried out between August and December 2014, in this place the mapping of a $42 \times 88 \mathrm{~m}$ mesh, with spacings of $6 \times 8 \mathrm{~m}$, totaling 88 sampling points at depths $0.0-0.05 ; 0.05-0.10$; $0.10-0.20 \mathrm{~m}$. At the crossing points of the mesh, soil blocks with preserved structure were collected at depths of $0.0-0.05 ; 0.05-0.10 ; 0.10-0.20 \mathrm{~m}$, to determine soil chemical attributes.

The $\mathrm{pH}$ was determined potentiometrically using water, in soil ratios: 1: 2.5 solution. $\mathrm{Ca}^{2+}$, $\mathrm{Mg}^{2+}$ and $\mathrm{Al}^{3+}$ were extracted with $1.0 \mathrm{~mol} \mathrm{~L}{ }^{-1} \mathrm{KCl}$ and titrated by titration. The $\mathrm{P}$ and $\mathrm{K}^{+}$were extracted with Mehlich $^{-1}$, the $\mathrm{P}$ measured by spectrophotometry, the $\mathrm{K}^{+}$by flame photometry. Potential acidity $(\mathrm{H}+\mathrm{Al})$ was extracted with $0.5 \mathrm{~mol}$ $\mathrm{L}^{-1}$ calcium acetate and titrated by titration (EMBRAPA, 2011).

The TOC was determined by wet combustion with potassium dichromate and titrated by titration from the Walkley and Black method modified by Yeomans and Bremner (1988).

The storage organic carbon (Sto C) was determined at all collection depths and was calculated by the expression (WELDKAMP, 1994). Sto $\mathrm{C}=($ TOC $\times$ BD $\times$ e $) / 10$, where:

Sto $\mathrm{C}=$ Storage organic carbon $\left(\mathrm{Mg} \mathrm{ha}^{-1}\right)$; TOC = total organic carbon content $\left(\mathrm{g} \mathrm{kg}^{-1}\right)$; $\mathrm{BD}=$ Bulk Density $\left(\mathrm{kg} \mathrm{dm}^{-3}\right)$; $\mathrm{e}=$ thickness of the layer considered (m).
Based on the results of the chemical analyzes, sums bases (SB), cation exchange capacity (CEC), base saturation (V \%).

\section{Statistical and geostatistical analysis}

Soil attributes were analyzed by means of descriptive statistical analysis, being determined the mean, median, coefficient of variation, skewness and kurtosis coefficient. The Kolmogorov-Smirnov (KS) test $(p \leq 0.05)$ was performed using Minitab 14 software (MINITAB, 2000).

Geostatistics was used to evaluate the spatial variability of the attributes studied, according to Vieira et al. (1983). In order to do the geostatistical analysis, it was necessary to know if there was spatial dependence or not of the attributes studied, which can be verified by means of the semivariogram graph.

The semivariogram is a graphical representation of the semivariance $y(h)$, represented in the $\mathrm{Y}$ coordinate, as a function of a given distance (h), represented in the $\mathrm{X}$ coordinate. In order to characterize the spatial variability, geostatistical analysis was used (Isaaks and Srivastava, 1989). Based on the assumption of stationarity of the intrinsic hypothesis, which the semivariogram is estimated by equation (1):

$$
\hat{\gamma}(h)=\frac{1}{2 N(h)} \sum_{i=1}^{N(h)}\left[Z\left(x_{i}\right)-Z\left(x_{i}+h\right)\right]^{2}
$$

Where: $\gamma(\mathrm{h})$ - the value of the semivariance for a distance $h ; N(h)$ - number of pairs involved in the semivariance calculation; $Z$ (xi) - value of attribute $\mathrm{Z}$ in position $\mathrm{xi}$; $\mathrm{Z}(\mathrm{xi}+\mathrm{h})$ - value of attribute $\mathrm{Z}$ separated by a distance $\mathrm{h}$ from position xi.

The adjustments of the experimental models to the semivariogram were based on the higher value of the coefficient of determination and the smaller value of the square root of the mean error, and the choice of the best fit was performed using the "Jack-Knifing" technique according to Vieira et al. (1983).

In order to analyze the degree of spatial dependence of soil attributes, Cambardella et al. (1994) classification was used, in which the semivariogram is considered a strong spatial dependence that has a nugget effect of $<25 \%$ of the plateau, moderate when it is between 25 and $75 \%$ and weak $>75 \%$.

After adjustment of the permissible mathematical models, the data were interpolated using kriging. Thus, the inverse of the square of the distance was used as interpolator for the attributes 
that did not present structure of spatial dependence. The geostatistical analysis was performed in Surfer software version 8.0 (GOLDEN SOFTWARE, 2002).

\section{RESULTS AND DISCUSSION}

\section{Descriptive statistics of chemical attributes}

The $\mathrm{pH}$ values in water in the evaluated layers ranged from 6.23 to 5.7 (Table 1). These results are similar to those found by Santos et al. (2013); Viana et al. (2016) from 4.3 to 6.6. The differences in $\mathrm{pH}$ variation in the soil studied with the other studies show the heterogenic nature of the occurrence of ADEs, either by the pedoenvironmental conditions or by the human activity in each place, in this way we can affirm that the $\mathrm{pH}$ indexes are presented as one of the indicative of the high natural fertility of these soils, in many cases $\mathrm{pH}$ values always higher than 5.5.

The $\mathrm{Ca}^{2+}$ and $\mathrm{Mg}^{2+}$ contents were higher in the superficial layer of 0.0-0.05 $\mathrm{m}$ and $0.05-0.10 \mathrm{~m}$, who stated that, in general, ADEs exhibit high levels of nutrients, mainly $\mathrm{Ca}$ and $\mathrm{P}$, from human and animal bone remains, as well as the formation of highly stable organic matter-calcium complexes (NOVOTNY et al., 2007; SANTOS et al., 2013).

The saturation by bases revealed high values in all layers evaluated between $77.25 \%$ and $52.65 \%$, characterizing them as well as eutrophic soils. Probably, the impact of anthropic action is not limited to the surface horizons, but it can alter the soil in depth, as a drastic reduction occurs with increasing depth (KERN; KÄMPF, 2005).

The levels of available phosphorus were high in the anthropogenic horizons, with a tendency to increase in depth, varying from 93.7 to $124.34 \mathrm{mg}$ $\mathrm{dm}^{-3}$, corroborating Campos et al. (2012); Santos et al. (2013); Viana et al. (2016). These results are due to the intensity of the incorporation of debris by the ancient inhabitants, as highlighted by Fraser \& Clement (2008), in a study on ADE soils in the Amazon region. The levels of exchangeable $\mathrm{Al}^{3+}$ were low in all strata evaluated (Table 1), similar to those observed Campos et al. (2012).

In relation to the cation exchange capacity (CEC), there was a clear trend of CEC decrease with soil depth, a behavior also observed by Glaser et al. (2000) and Santos et al. (2013) in studies of ADEs in the Amazon. The highest base sum results were observed in the superficial layer of $0.0-0.05 \mathrm{~m}$, when comparing subsurface layers, which ranged from 21.77 to $12.59 \mathrm{cmolc} \mathrm{dm}^{-3}$, thus indicating the tendency of base reduction when increasing depth and increase occur relative to the $\mathrm{Al}^{3+}$ content.
The organic carbon (O.C) contents ranged from 55.31 to $31.31 \mathrm{~g} \mathrm{~kg}^{-1}$, decreasing with soil depth. Similar results were obtained by Campos et al. (2012); Santos et al. (2013). The high carbon content in the ADEs can be attributed to the composition of organic matter rich in pyrogenic carbon (coal), added to the soil by the activity of pre-Columbian indigenous peoples (GLASER et al., 2000). In relation to the storage carbon, the high indexes are attributed to the anthropic changes that this soil suffered in its formation. Falcão and Borges (2006) report that ADE areas present high levels of organic matter and more intense biological activity than non-anthropogenic soils, the authors say that these high values can come from human and animal remains.

The results referring to the descriptive analysis of the chemical attributes are presented in (Table 1). The values of the central tendency measures (mean and median) are close for all variables, justifying values of skewness and kurtosis close to zero, except for acidity and V\% at depth $0.05-0.10 \mathrm{~m}$ and $\mathrm{Al}^{3+}$ and $\mathrm{V} \%$ at depth $0.10-0.20 \mathrm{~m}$.

The skewness coefficient is used to characterize how and how much the frequency distribution moves away from the symmetry. So that if the value found for this coefficient is zero, the distribution is symmetric, if positive, the distribution is asymmetric on the right, and if negative, is asymmetric on the left (ALHO et al., 2014). Taking into account this understanding, it was verified that most of the variables presented positive asymmetric coefficients, except for the variables $\mathrm{Ca}, \mathrm{SB}$ and $\mathrm{V} \%$ in the layer 0.0-0.05 m; SB, CEC and V\% in the 0.05-0.10 m layer and O.C, $\mathrm{H}+\mathrm{Al}$ and CEC in the respective $0.10-0.20 \mathrm{~m}$ layer, both exceptions characterized as negative asymmetric coefficients (Table 1). Although asymmetric distributions were found, there was some evidence that, because of the similarity between the mean and median values and the results of the skewness and kurtosis coefficients close to zero, they presented for most of the evaluated variables, these results show That measures of central tendency are not dominated by atypical values in the distribution. According to Cambardella et al. (1994), such results indicate that the data are suitable for the application of geostatistics.

In relation to the classification of the coefficient of variation $(\mathrm{CV})$ proposed by (Warrick \& Nielsen, 1980), it was observed that the $\mathrm{pH}$ and CEC variables in depth $0.0-0.05 \mathrm{~m}$, and O.C and CEC in depth $0.05-0.10 \mathrm{~m}$ and CEC at depth 0.10 $0.20 \mathrm{~m}$ presented low variability of data, while all others presented medium variability. No attribute, 
therefore, presented high variability. Taking into account the standards established by Nogueira (2007), which states that a coefficient of variation greater than $35 \%$ reveals that the series is heterogeneous and the mean has little meaning, and if it is greater than $65 \%$, the series is described as very heterogeneous and the mean has no meaning, but if, however, it is less than $35 \%$, the series is homogeneous and the mean has significance and can be used as representative of the series. Series from where it was obtained. In this way, according to the results we can say that most of the attributes behaved presenting series of homogeneous data and the mean presenting meaning.

Table 1. Descriptive statistics of chemical attributes on Archeological Dark Earth under Cacao cultivation in Western Amazonia.

\begin{tabular}{|c|c|c|c|c|c|c|c|c|c|}
\hline $\begin{array}{l}\text { Descriptive } \\
\text { Statistics }\end{array}$ & Mean & Median & SD & ${ }^{1} \mathrm{CV}(\%)$ & Min. & Max. & Skewness & Kurtosis & $\mathrm{d}$ \\
\hline \multicolumn{10}{|l|}{$0.0-0.05 \mathrm{~m}$} \\
\hline $\mathrm{pH}\left(\mathrm{H}_{2} \mathrm{O}\right)$ & 6.23 & 6.08 & 0.65 & 10.43 & 4.49 & 7.53 & 0.08 & -0.56 & $0.03^{\mathrm{ns}}$ \\
\hline O.C $\left(\mathrm{g} \mathrm{kg}^{-1}\right)$ & 55.31 & 54.71 & 10.94 & 19.77 & 27.96 & 83.76 & 0.19 & 0.04 & $0.20 *$ \\
\hline Sto $C\left(\mathrm{~g} \mathrm{~kg}^{-1}\right)$ & 24.74 & 23.39 & 5.32 & 21.50 & 11.60 & 38.97 & 0.24 & -0.01 & $0.00^{\text {ns }}$ \\
\hline $\mathrm{H}+\mathrm{Al}\left(\mathrm{cmol}_{\mathrm{c}} \mathrm{dm}^{-3}\right)$ & 6.54 & 6.43 & 3.44 & 52.59 & 1.16 & 15.06 & 0.36 & -0.59 & $0.07 *$ \\
\hline $\mathrm{Al}^{3+}\left(\mathrm{cmol}_{\mathrm{c}} \mathrm{dm}^{-3}\right)$ & 0.06 & 0.06 & 0.01 & 16.66 & 0.04 & 0.10 & 0.26 & -0.54 & $0.00^{\mathrm{ns}}$ \\
\hline $\mathrm{P}\left(\mathrm{mg} \mathrm{dm}^{-3}\right)$ & 93.70 & 94.12 & 32.73 & 34.93 & 30.38 & 170.66 & 0.33 & -0.43 & $0.20 *$ \\
\hline $\mathrm{K}\left(\mathrm{cmol}_{\mathrm{c}} \mathrm{dm}^{-3}\right)$ & 0.03 & 0.02 & 0.01 & 33.33 & 0.00 & 0.05 & 0.55 & -0.29 & $0.04^{\mathrm{ns}}$ \\
\hline $\mathrm{Ca}\left(\mathrm{cmol}_{\mathrm{c}} \mathrm{dm}^{-3}\right)$ & 19.57 & 20.00 & 3.20 & 16.35 & 12.75 & 26.25 & -0.29 & -0.50 & $0.20 *$ \\
\hline $\mathrm{Mg}\left(\mathrm{cmol}_{\mathrm{c}} \mathrm{dm}^{-3}\right)$ & 2.12 & 2.13 & 1.06 & 50.00 & 0.25 & 5.00 & 0.47 & -0.09 & $0.20 *$ \\
\hline $\mathrm{SB}\left(\mathrm{cmol}_{\mathrm{c}} \mathrm{dm}^{-3}\right)$ & 21.77 & 21.76 & 3.27 & 15.03 & 13.27 & 27.75 & -0.53 & -0.09 & $0.20 *$ \\
\hline $\mathrm{CEC}\left(\mathrm{cmol}_{\mathrm{c}} \mathrm{dm}^{-3}\right)$ & 28.28 & 28.06 & 2.78 & 9.83 & 21.90 & 34.35 & 0.01 & -0.33 & $0.20 *$ \\
\hline $\mathrm{V} \%$ & 77.25 & 76.85 & 11.25 & 14.56 & 47.74 & 94.81 & -0.42 & -0.32 & $0.20 *$ \\
\hline \multicolumn{10}{|l|}{$0.05-0.10 \mathrm{~m}$} \\
\hline $\mathrm{pH}\left(\mathrm{H}_{2} \mathrm{O}\right)$ & 6.13 & 6.01 & 0.78 & 12.72 & 4.78 & 7.78 & 0.48 & -0.55 & $0.05^{*}$ \\
\hline O.C $\left(\mathrm{g} \mathrm{kg}^{-1}\right)$ & 40.41 & 39.40 & 4.15 & 10.26 & 30.56 & 51.40 & 0.31 & -0.09 & $0.01^{\mathrm{ns}}$ \\
\hline Sto $C\left(\mathrm{~g} \mathrm{~kg}^{-1}\right)$ & 19.36 & 18.98 & 2.85 & 14.72 & 13.83 & 26.53 & 0.52 & -0.03 & $0.20 *$ \\
\hline $\mathrm{H}+\mathrm{Al}\left(\mathrm{cmol}_{\mathrm{c}} \mathrm{dm}^{-3}\right)$ & 9.15 & 8.58 & 4.97 & 54.31 & 0.99 & 19.64 & 0.19 & -1.00 & $0.15^{*}$ \\
\hline $\mathrm{Al}^{3+}\left(\mathrm{cmol}_{\mathrm{c}} \mathrm{dm}^{-3}\right)$ & 0.07 & 0.08 & 0.03 & 42.85 & 0.03 & 0.17 & 0.76 & 0.33 & $0.00^{\text {ns }}$ \\
\hline$P\left(\mathrm{mg} \mathrm{dm}^{-3}\right)$ & 109.61 & 110.62 & 33.63 & 30.68 & 35.22 & 198.32 & 0.01 & -0.25 & $0.20 *$ \\
\hline $\mathrm{K}\left(\mathrm{cmol}_{\mathrm{c}} \mathrm{dm}^{-3}\right)$ & 0.03 & 0.02 & 0.01 & 33.33 & 0.01 & 0.05 & 0.40 & -0.14 & $0.17 *$ \\
\hline $\mathrm{Ca}\left(\mathrm{cmol}_{\mathrm{c}} \mathrm{kg}^{-3}\right)$ & 11.60 & 11.95 & 3.95 & 34.05 & 3.40 & 21.50 & 0.20 & -0.32 & $0.02^{\text {ns }}$ \\
\hline $\mathrm{Mg}\left(\mathrm{cmol}_{\mathrm{c}} \mathrm{dm}^{-3}\right)$ & 4.05 & 4.00 & 1.47 & 36.29 & 0.95 & 7.10 & 0.06 & -0.79 & $0.20 *$ \\
\hline $\mathrm{SB}\left(\mathrm{cmol}_{\mathrm{c}} \mathrm{dm}^{-3}\right)$ & 15.89 & 15.91 & 4.65 & 29.26 & 5.16 & 24.81 & -0.09 & -0.74 & $0.20 *$ \\
\hline CEC $\left(\mathrm{cmol}_{\mathrm{c}} \mathrm{dm}^{-3}\right)$ & 25.75 & 25.90 & 2.05 & 7.96 & 20.98 & 29.83 & -0.14 & -0.62 & $0.20 *$ \\
\hline V\% & 63.96 & 64.89 & 18.33 & 28.65 & 30.87 & 96.02 & -0.05 & -1.06 & $0.18 *$ \\
\hline \multicolumn{10}{|l|}{$0.10-0.20 \mathrm{~m}$} \\
\hline $\mathrm{pH}\left(\mathrm{H}_{2} \mathrm{O}\right)$ & 5.70 & 5.52 & 0.75 & 13.15 & 4.58 & 7.95 & 0.88 & 0.10 & $0.00^{\text {ns }}$ \\
\hline O.C $\left(\mathrm{g} \mathrm{kg}^{-1}\right)$ & 31.31 & 31.78 & 5.45 & 17.40 & 20.11 & 43.45 & $\begin{array}{l}0.00 \\
-0.15\end{array}$ & -0.35 & $0.20 *$ \\
\hline Sto $C\left(\mathrm{~g} \mathrm{~kg}^{-1}\right)$ & 29.81 & 29.68 & 6.18 & 20.73 & 13.86 & 45.62 & 0.04 & 0.03 & $0.20 *$ \\
\hline $\mathrm{H}+\mathrm{Al}\left(\mathrm{cmol}_{\mathrm{c}} \mathrm{dm}^{-3}\right)$ & 11.53 & 12.12 & $\begin{array}{l}0.10 \\
4.98\end{array}$ & 43.19 & 1.32 & 22.11 & $\begin{array}{l}0.04 \\
-0.22\end{array}$ & -0.96 & $0.08 *$ \\
\hline $\mathrm{Al}\left(\mathrm{cmol}_{\mathrm{c}} \mathrm{dm}^{-3}\right)$ & 0.08 & 0.08 & 0.03 & 37.50 & 0.04 & 0.20 & 1.12 & 0.51 & $0.00^{\text {ns }}$ \\
\hline $\mathrm{P}\left(\mathrm{mg} \mathrm{dm}^{-3}\right)$ & 124.34 & 126.23 & 30.39 & 24.44 & 48.29 & 191.64 & 0.04 & -0.22 & $0.20 *$ \\
\hline $\mathrm{K}\left(\mathrm{cmol}_{\mathrm{c}} \mathrm{dm}^{-3}\right)$ & 0.02 & 0.01 & 0.01 & 50.00 & 0.00 & 0.05 & 0.91 & 0.26 & $0.00^{\text {ns }}$ \\
\hline $\mathrm{Ca}\left(\mathrm{cmol}_{\mathrm{c}} \mathrm{dm}^{-3}\right)$ & 10.47 & 10.31 & 4.29 & 40.97 & $\begin{array}{l}0.00 \\
2.75\end{array}$ & 20.38 & 0.40 & -0.44 & $0.20 *$ \\
\hline $\mathrm{Mg}\left(\mathrm{cmol}_{\mathrm{c}} \mathrm{dm}^{-3}\right)$ & 1.99 & 2.00 & 1.00 & 50.25 & 0.38 & 4.88 & 0.43 & -0.15 & $0.20 *$ \\
\hline $\mathrm{SB}\left(\mathrm{cmol}_{\mathrm{c}} \mathrm{dm}^{-3}\right)$ & 12.59 & 12.46 & 4.40 & 34.94 & 5.51 & $\begin{array}{l}4.00 \\
22.78\end{array}$ & 0.31 & -0.85 & $0.05 *$ \\
\hline $\mathrm{CEC}\left(\mathrm{cmol}_{\mathrm{c}} \mathrm{dm}^{-3}\right)$ & 24.46 & 24.61 & 1.88 & 7.68 & 20.36 & 29.25 & -0.25 & -0.12 & $0.02^{\mathrm{ns}}$ \\
\hline $\mathrm{V} \%$ & 52.65 & 51.69 & 19.06 & 36.20 & 23.07 & 93.78 & 0.33 & -1.04 & $0.02^{\mathrm{ns}}$ \\
\hline
\end{tabular}

$\mathrm{SD}=$ Standard Deviation, CV = Coefficient of Variation, Min = Minimum, Max = Maximum, $\mathrm{d}=$ Normal test of Kolmogorov Smirnov, * Significant at the 5\% probability level, OC = Organic Carbon; CEC $=$ Cation Exchange Capacity, SB $=$ Sum Base, V\% $=$ Saturation Base, Sto $\mathrm{C}=$ Storage organic carbon. 


\section{Geostatistical analysis}

The chemical attributes of the soil were adjusted to the spherical and exponential semivariograms models (Table 2). Studies related to the spatial variability of soil attributes have shown that the spherical and exponential models have been the most frequent (AMADO et al., 2009; SANCHEZ et al., 2009; SIQUEIRA et al., 2010; DALCHIAVON et al., 2012). In addition, therefore, the adjusted models found in the present study are in agreement with the research done on soil variability. Another factor observing in the present results was the predominance of the adjustment to the spherical semivariogram model, in the depths $0.0-0.05 \mathrm{~m}$ and $0.05-0.10 \mathrm{~m}$. In this work, the spherical model is the most cited by researchers as being more common in studies related to the attributes of soil and plant (VIEIRA et al., 2011).

All the chemical attributes studied showed a coefficient of determination $\left(\mathrm{R}^{2}\right)$ above 0.70 (Table 2 ), that is, at least $70 \%$ of the variability in the values of the estimated semivariance are explained by the adjusted models (CAMPOS et al., 2007). According to Azevedo (2004) when $\mathrm{R}^{2}$ is higher than 0.5 , the better the estimation of values by the ordinary kriging method. The cross-validations representing the adjusted models showed a good performance, with values varying from 0.75 to 0.98 .

At the distance at which the semivariance stabilizes is considered the extent of spatial dependence. The variables that underwent different spatial dependence, the lowest range was $\mathrm{K}^{+}(12 \mathrm{~m})$, depth $0.0-0.05 \mathrm{~m}$, and the highest observed was for CEC (64 m), in the depth 0.10-0.20 m.

There were attributes that the distance of collection of the sample points in the field was not enough to characterize the spatial variability, presenting pure nugget effect. It was the case of O.C and Sto $\mathrm{C}$ at depth $0.0-0.05 \mathrm{~m}$, and O.C at depth $0.10-0.20 \mathrm{~m}$. When the studied variable is spatially independent, its $\mathrm{C}_{0}$ (nugget effect) is equal to $\mathrm{C}_{1}+\mathrm{C}_{0}$ (plateau), known as pure nugget effect (PNE). PNE is important and indicates a random distribution, ie, unexplained variability or undetected variation, and may occur due to undetected measurements, sampling or microvariation errors, considering that the sampling spacing used is greater than necessary to detect the dependence (CAMBARDELLA et al., 1994).

The relationship between the $\mathrm{C}_{\mathrm{o}} /\left(\mathrm{C}_{\mathrm{o}}+\mathrm{C}_{1}\right)$ ratio was expressed according to the classification proposed by (CAMBARDELLA et al., 1994), where the semivariograms with spatial dependence less than or equal to $25 \%$ have a strong spatial dependence. Is moderate when this ratio varies from 25 to $75 \%$ and is weak if this value exceeds $75 \%$ according to this classification. The attribute that presented a spatial dependence (SD) between 25 and $75 \%$ was only $\mathrm{Ca}, \mathrm{Mg}$ and $\mathrm{CEC}$ at depth $0.05-0.10$ $\mathrm{m}$, and $\mathrm{P}$ and $\mathrm{CEC}$ and $\mathrm{V} \%$ at depth $0.10-0.20 \mathrm{~m}$. The other attributes studied presented SD less than or equal $25 \%$, thus presenting Zanão Júnior et al. (2007), which highlights the importance of knowledge of spatial dependence structure.

Points out that the variables that have a strong spatial dependence are more influenced by the intrinsic properties of the soil, that is, by the soil formation factors, while the moderate spatial dependence is due to the homogenization of the soil, whereas to the extrinsic attributes weak dependence (CAMBARDELLA et al., 1994).

Table 2. Estimated models and parameters to semivariograms of chemical attributes on Archeological Dark Earth under Cacao cultivation in Western Amazonia.

\begin{tabular}{llllllll}
\hline Parameters & Model & NE & Sill & Range $(\mathrm{m})$ & SD & $\mathrm{R}^{2}$ & $\mathrm{CV}$ \\
\hline $0.0-0.05 \mathrm{~m}$ & & & & & & & \\
\hline $\mathrm{pH}\left(\mathrm{H}_{2} \mathrm{O}\right)$ & Sph. & 0.01 & 0.38 & 25.00 & 2.63 & 0.85 & 0.97 \\
$\mathrm{O} . \mathrm{C}\left(\mathrm{g} \mathrm{kg}^{-1}\right)$ & - & - & - & - & PNE & - & - \\
$\mathrm{Sto} \mathrm{C}\left(\mathrm{g} \mathrm{kg}^{-1}\right)$ & - & - & - & - & PNE & - & - \\
$\mathrm{H}+\mathrm{Al}\left(\mathrm{cmol}_{\mathrm{c}} \mathrm{dm}^{-3}\right)$ & Sph. & 1.00 & 14.33 & 30.00 & 6.97 & 0.89 & 0.86 \\
$\mathrm{Al}^{3+}\left(\mathrm{cmol}_{\mathrm{c}} \mathrm{dm}^{-3}\right)$ & Sph. & 0.00 & 0.00 & 30.00 & 7.50 & 0.80 & 0.93 \\
$\mathrm{P}\left(\mathrm{mg} \mathrm{dm}^{-3}\right)$ & Sph. & 2980,00 & 16670,00 & 30.00 & 17.87 & 0.97 & 0.78 \\
$\mathrm{~K}\left(\mathrm{cmol}_{\mathrm{c} \mathrm{dm}}{ }^{-3}\right)$ & Sph. & 0.00 & 0.00 & 12.00 & 6.00 & 0.98 & 0.75 \\
$\mathrm{Ca}\left(\mathrm{cmol}_{\mathrm{c}} \mathrm{dm}^{-3}\right)$ & Sph. & 0.13 & 9.88 & 24.00 & 1.31 & 0.83 & 0.83 \\
$\mathrm{Mg}\left(\mathrm{cmol}_{\mathrm{c}} \mathrm{dm}^{-3}\right)$ & Exp. & 0.10 & 0.96 & 30.00 & 10.41 & 0.89 & 0.94 \\
$\mathrm{SB}\left(\mathrm{cmol}_{\mathrm{c}} \mathrm{dm}^{-3}\right)$ & Exp. & 0.91 & 9.47 & 22.50 & 9.60 & 0.83 & 0.90 \\
$\mathrm{CEC}\left(\mathrm{cmol}_{\mathrm{c}} \mathrm{dm}^{-3}\right)$ & Exp. & 0.65 & 7.87 & 24.00 & 8.25 & 0.79 & 0.77 \\
$\mathrm{~V} \%$ & Sph. & 31.00 & 130.90 & 29.00 & 23.68 & 0.98 & 0.90 \\
\hline $0.05-0.1 \mathrm{~m}$ & & & & & &
\end{tabular}




\begin{tabular}{|c|c|c|c|c|c|c|c|}
\hline $\mathrm{pH}\left(\mathrm{H}_{2} \mathrm{O}\right)$ & Sph. & 0.01 & 0.62 & 30.00 & 0.87 & 1.61 & 0.81 \\
\hline $\mathrm{O} . \mathrm{C}\left(\mathrm{g} \mathrm{kg}^{-1}\right)$ & Sph. & 2.10 & 55.31 & 22.00 & 0.74 & 3.79 & 0.88 \\
\hline Sto $\mathrm{C}\left(\mathrm{g} \mathrm{kg}^{-1}\right)$ & Sph. & 1.11 & 13.76 & 27.00 & 0.82 & 8.06 & 0.89 \\
\hline $\mathrm{H}+\mathrm{Al}\left(\mathrm{cmol}_{\mathrm{c}} \mathrm{dm}^{-3}\right)$ & Sph. & 1.01 & 25.52 & 30.00 & 0.88 & 3.67 & 0.96 \\
\hline $\mathrm{Al}^{3+}\left(\mathrm{cmol}_{\mathrm{c}} \mathrm{dm}^{-3}\right)$ & Sph. & 0.00 & 0.00 & 27.00 & 0.86 & 5.00 & 0.91 \\
\hline $\mathrm{P}\left(\mathrm{mg} \mathrm{dm}^{-3}\right)$ & Exp. & 156.00 & 1407,00 & 20.00 & 0.84 & 11.08 & 0.76 \\
\hline $\mathrm{K}\left(\mathrm{cmol}_{\mathrm{c}} \mathrm{dm}^{-3}\right)$ & Exp.. & 0.00 & 0.00 & 20.00 & 0.80 & 10.00 & 0.83 \\
\hline $\mathrm{Ca}\left(\mathrm{cmol}_{\mathrm{c}} \mathrm{dm}^{-3}\right)$ & Sph. & 4.98 & 16.12 & 36.00 & 091 & 30.89 & 0.94 \\
\hline $\operatorname{Mg}\left(\mathrm{cmol}_{\mathrm{c}} \mathrm{dm}^{-3}\right)$ & Sph. & 0.70 & 2.13 & 55.80 & 0.94 & 32.86 & 0.95 \\
\hline $\mathrm{SB}\left(\mathrm{cmol}_{\mathrm{c}} \mathrm{dm}^{-3}\right)$ & Sph. & 0.53 & 19.99 & 22.00 & 0.87 & 2.65 & 0.82 \\
\hline $\operatorname{CEC}\left(\mathrm{cmol}_{\mathrm{c}} \mathrm{dm}^{-3}\right)$ & Sph. & 4.54 & 9.18 & 60.00 & 0.90 & 49.45 & 0.80 \\
\hline V\% & Sph. & 14.90 & 328.20 & 24.40 & 0.84 & 4.53 & 0.83 \\
\hline \multicolumn{8}{|l|}{$0.1-0.2 \mathrm{~m}$} \\
\hline $\mathrm{pH}\left(\mathrm{H}_{2} \mathrm{O}\right)$ & Sph. & 0.01 & 0.53 & 30.00 & 0.90 & 1.88 & 0.81 \\
\hline O.C $\left(\mathrm{g} \mathrm{kg}^{-1}\right)$ & - & - & - & - & - & PNE & - \\
\hline Sto $\mathrm{C}\left(\mathrm{g} \mathrm{kg}^{-1}\right)$ & Sph. & 1.10 & 38.64 & 25.64 & 0.93 & 2.84 & 0.84 \\
\hline $\mathrm{H}+\mathrm{Al}\left(\mathrm{cmol}_{\mathrm{c}} \mathrm{dm}^{-3}\right)$ & Sph. & 0.20 & 25.18 & 30.00 & 0.92 & 0.79 & 0.92 \\
\hline $\mathrm{Al}^{3+}\left(\mathrm{cmol}_{\mathrm{c}} \mathrm{dm}^{-3}\right)$ & Exp. & 0.01 & 0.05 & 40.00 & 0.86 & 20.00 & 0.86 \\
\hline $\mathrm{P}\left(\mathrm{mg} \mathrm{dm}^{-3}\right)$ & Exp. & 378.00 & 991.80 & 25.00 & 0.93 & 38.11 & 0.78 \\
\hline $\mathrm{K}\left(\mathrm{cmol}_{\mathrm{c}} \mathrm{dm}^{-3}\right)$ & Exp. & 0.00 & 0.00 & 15.00 & 0.98 & 3.33 & 0.73 \\
\hline $\mathrm{Ca}\left(\mathrm{cmol}_{\mathrm{c}} \mathrm{dm}^{-3}\right)$ & Sph. & 0.34 & 19.22 & 28.00 & 0.94 & 1.76 & 0.93 \\
\hline $\mathrm{Mg}\left(\mathrm{cmol}_{\mathrm{c}} \mathrm{dm}^{-3}\right)$ & Exp. & 0.10 & 1.16 & 33.00 & 0.86 & 8.62 & 0.94 \\
\hline $\mathrm{SB}\left(\mathrm{cmol}_{\mathrm{c}} \mathrm{dm}^{-3}\right)$ & Sph. & 0.60 & 17.66 & 26.20 & 0.97 & 3.39 & 0.90 \\
\hline $\operatorname{CEC}\left(\mathrm{cmol}_{\mathrm{c}} \mathrm{dm}^{-3}\right)$ & Sph. & 2.83 & 6.11 & 64.00 & 0.76 & 46.31 & 0.97 \\
\hline V\% & Sph. & 134.40 & 313.50 & 38.60 & 0.93 & 42.87 & 0.98 \\
\hline
\end{tabular}

$\mathrm{NE}=$ Nugget effect, $\mathrm{SD}=$ Spatial Dependence, $\mathrm{CV}=$ Cross Validation, OC = Organic Carbon, CEC $=$ Cation Exchange Capacity, SB = Sum Base, $\mathrm{V} \%=$ Saturation Base, $\mathrm{Sph}=$ Spherical, Exp $=$ Exponential, $\mathrm{PNE}=$ Pure Nugget Effect, Sto $\mathrm{C}=$ Storage organic carbon

\section{Kriging maps of soil chemical attributes}

From the semivariogram adjustments, the kriging maps were constructed (Figure 2). Maps are fundamental parts of precision agriculture, since they are subsequently geoprocessed, in order to assist in the correct use and management of the soil.

Kriging is the interpolated surface of each variable, which shows the spatial distribution. Through kriging, it is possible to identify the location and coverage of extreme values, the degree of homogeneity of the area and the directions of larger gradients (GUIMARÃES et al., 2016). The use of sampling optimization maps provides information that allows you to better understand the spatial distribution pattern and define management zones. These maps can be very useful in experimental planning and as a tool for precision agriculture programs (MONTANARI et al., 2005). The spatial distribution maps of the studied variables should be presented in five regular intervals of specific values for each variable, allowing a greater understanding of the distribution, especially those with small intervals between maximum and minimum values.

Particularly from the maps generated for the chemical attributes, one can identify that the spatial distribution pattern is quite variable throughout the study area, because for all variables that presented spatial dependence structure, the distribution spots are heterogeneous, thus characterizing sufficient information that Archeological Dark Earths exhibit spatial heterogeneity in their distribution. 
Depths of 0.0-0.05 m

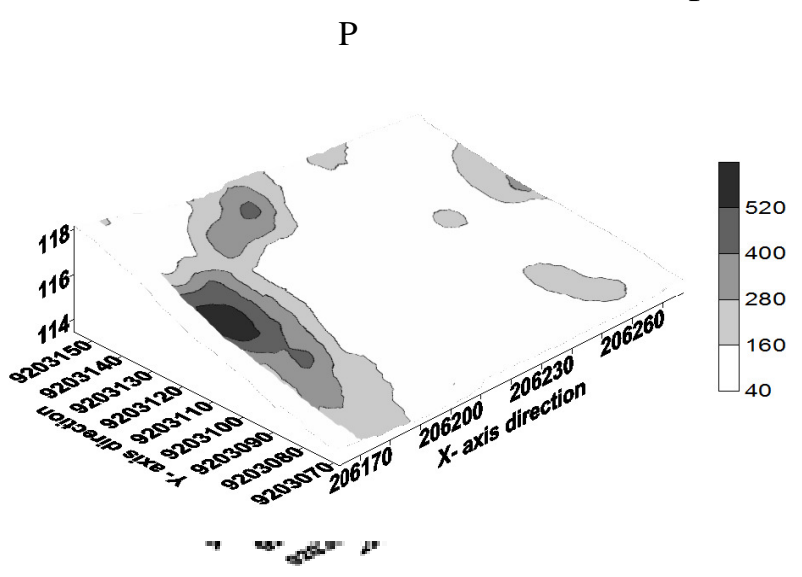

$\mathrm{Ca}$

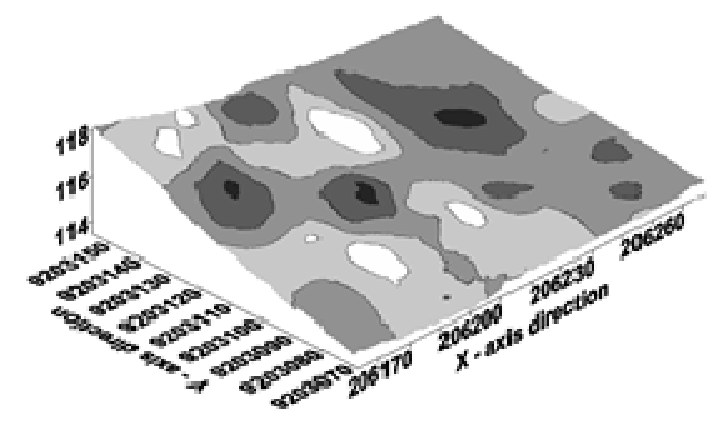

$\mathrm{pH}$

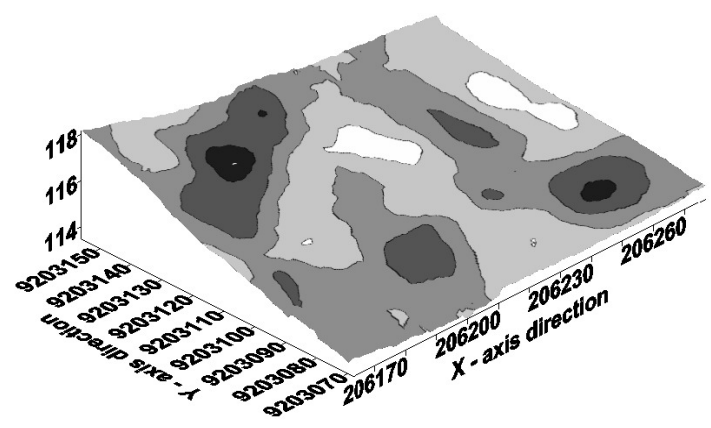

SE

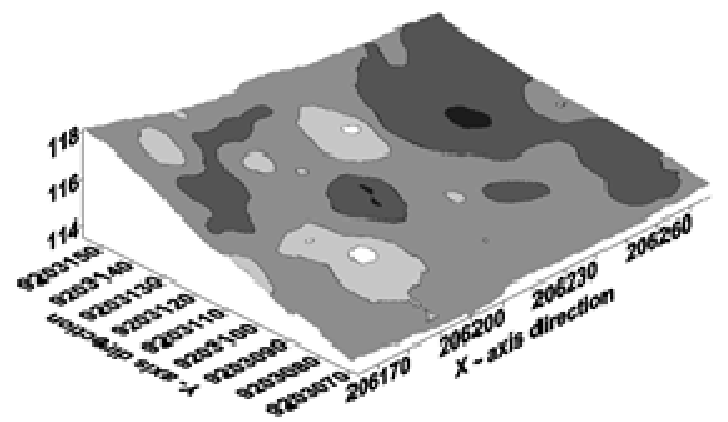

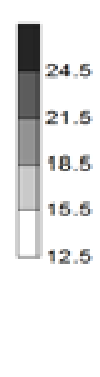

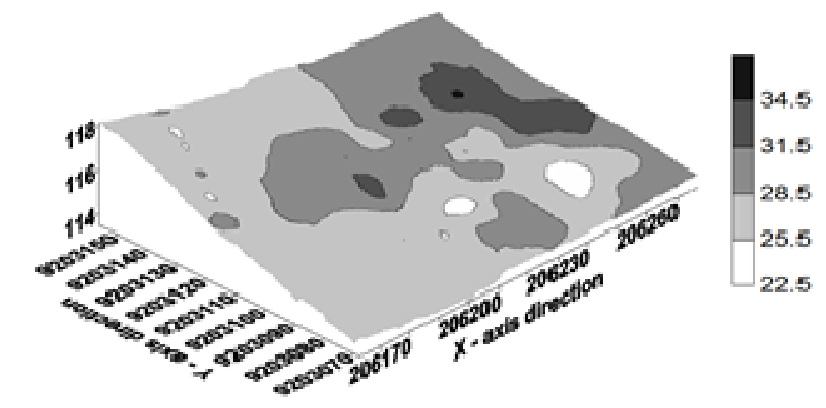

K
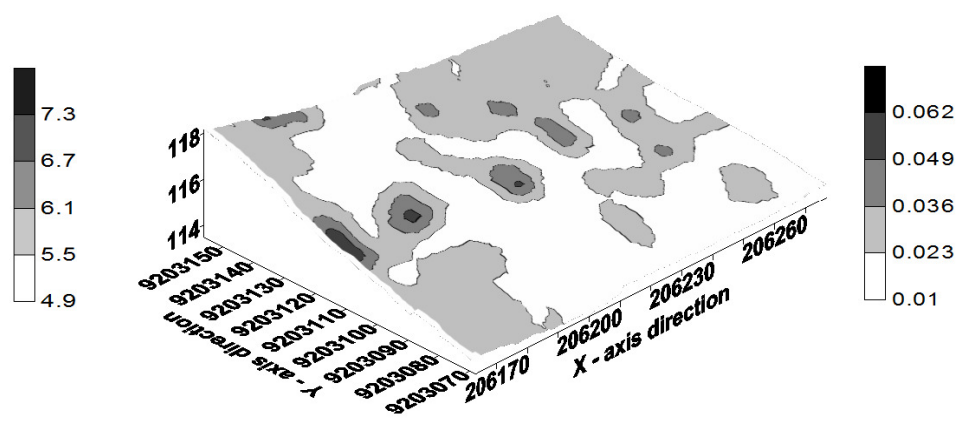

$\mathrm{V} \%$
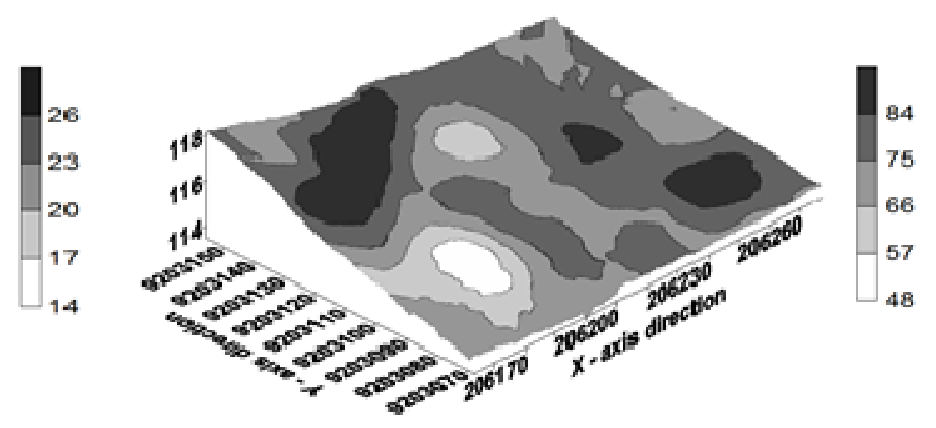

$\mathrm{H}+\mathrm{Al}$
Depth of $0.05-0.10 \mathrm{~m}$
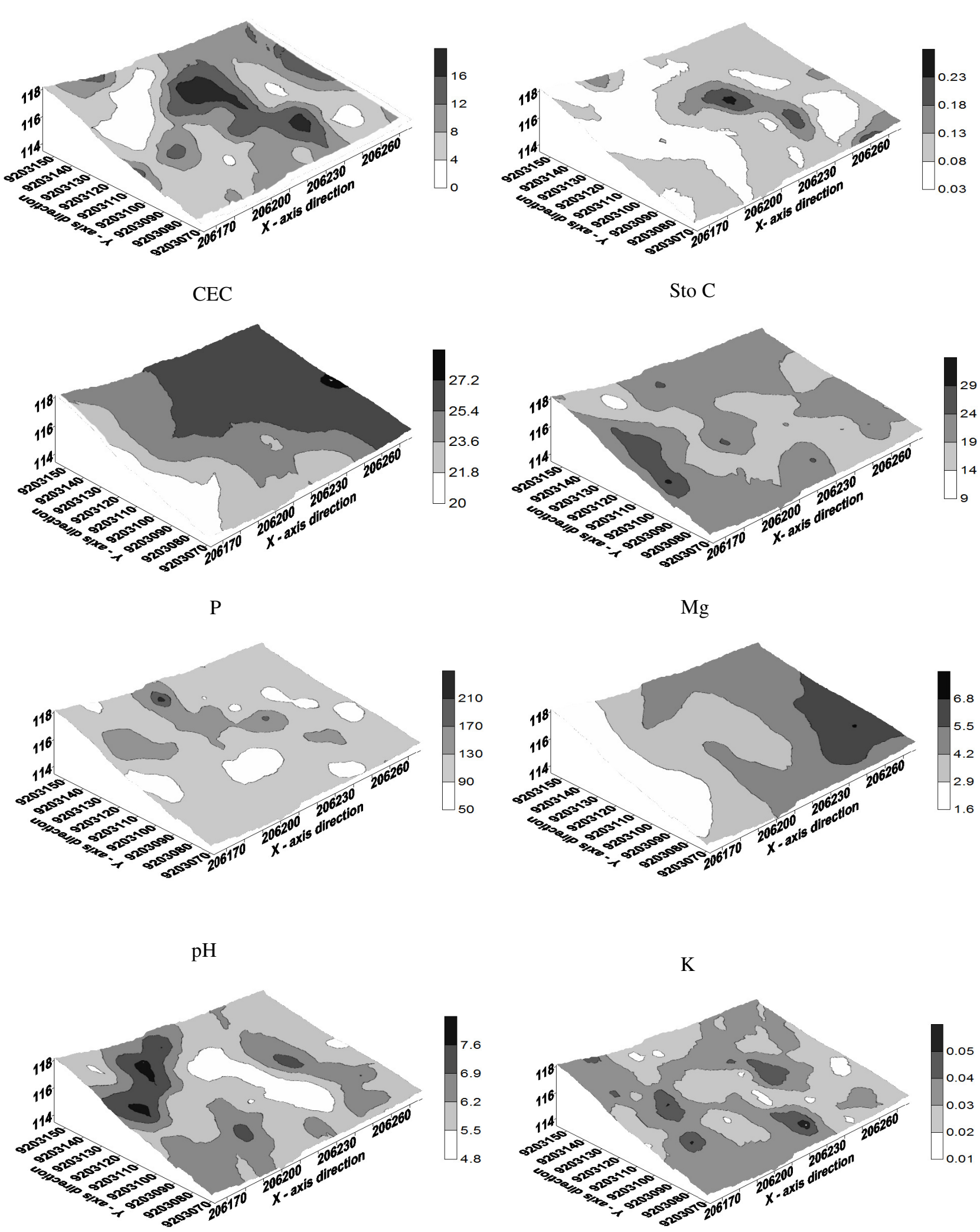


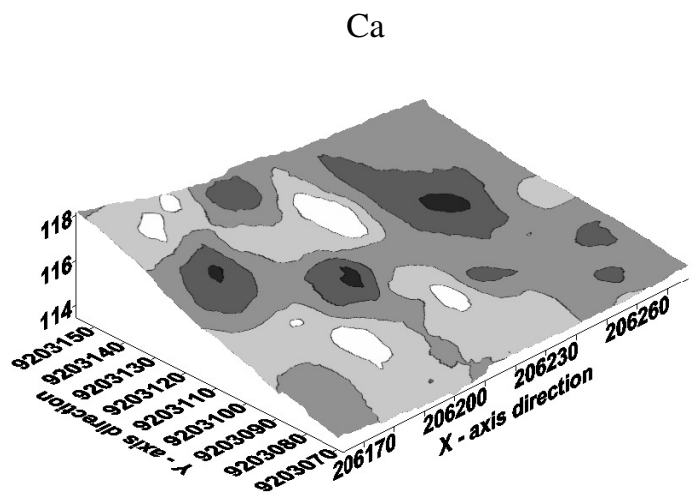

SB

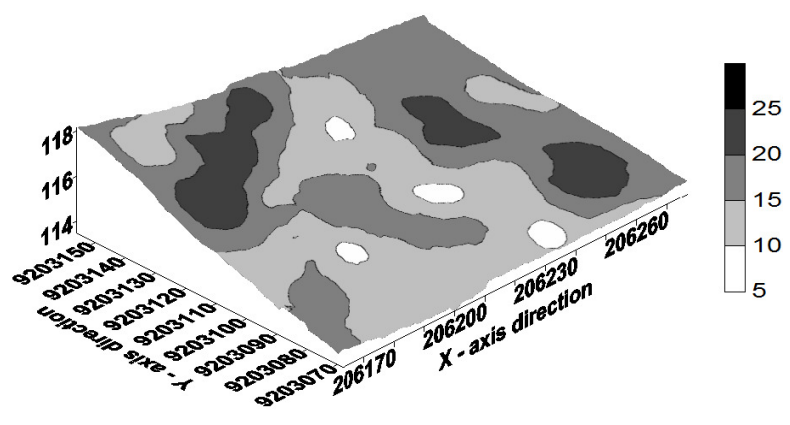

O.C

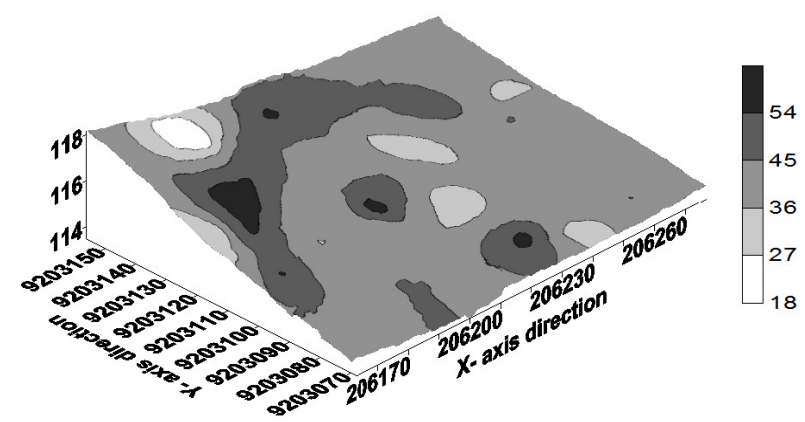

$\mathrm{V} \%$

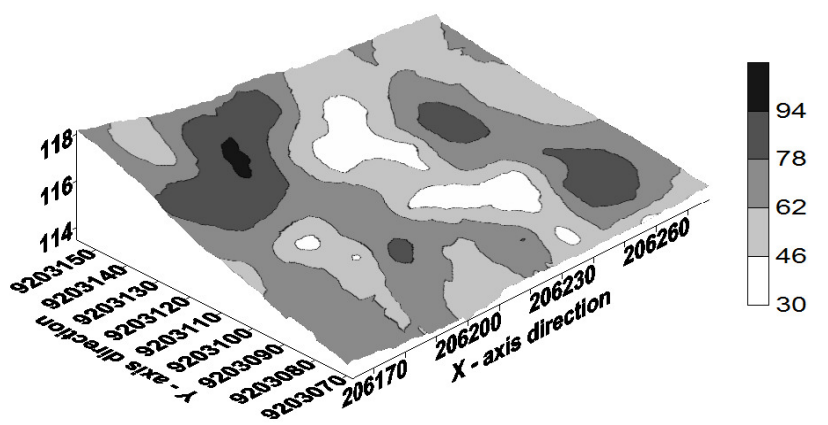

Depth of $0.10-0.20 \mathrm{~m}$
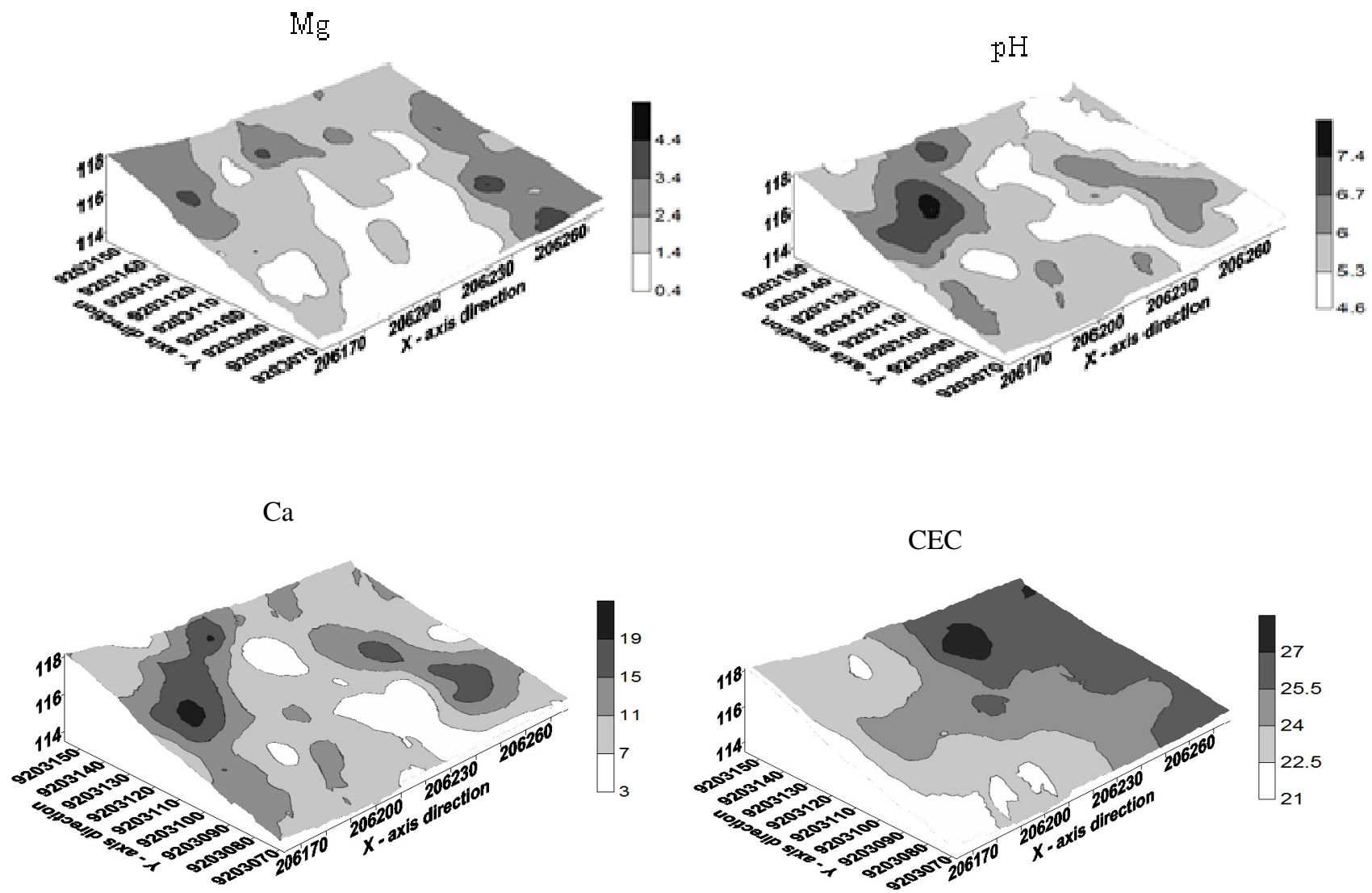


$$
-
$$

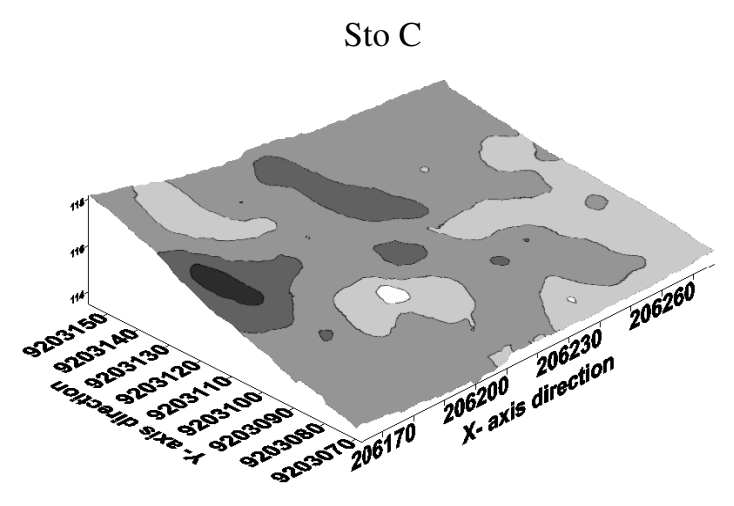

$$
\text { mant }
$$
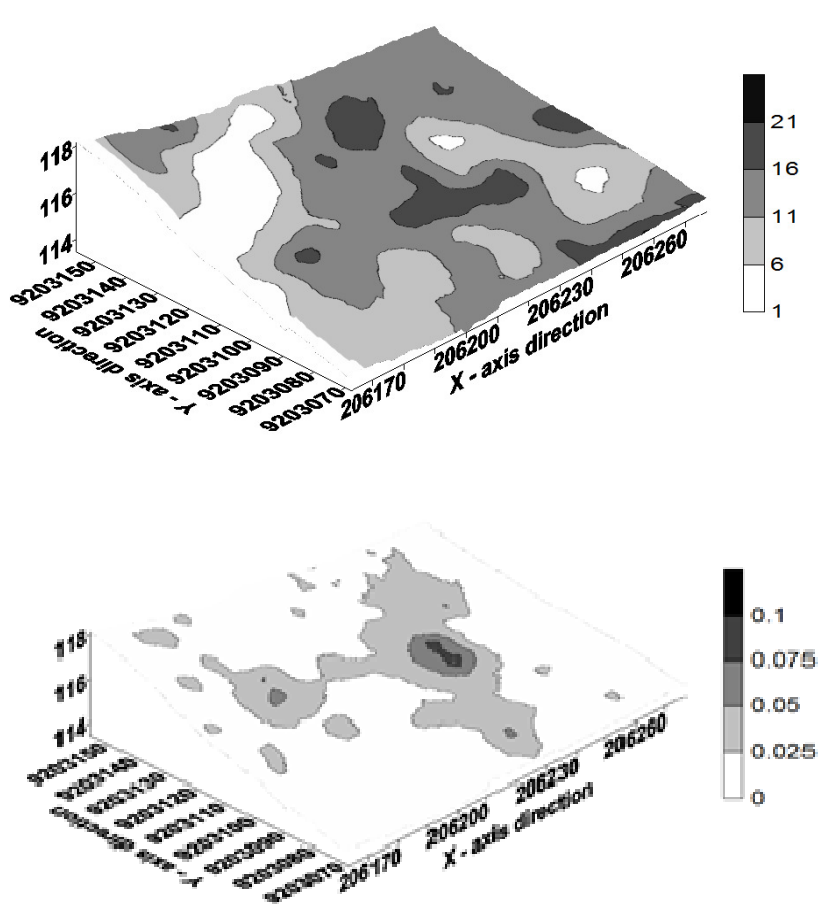

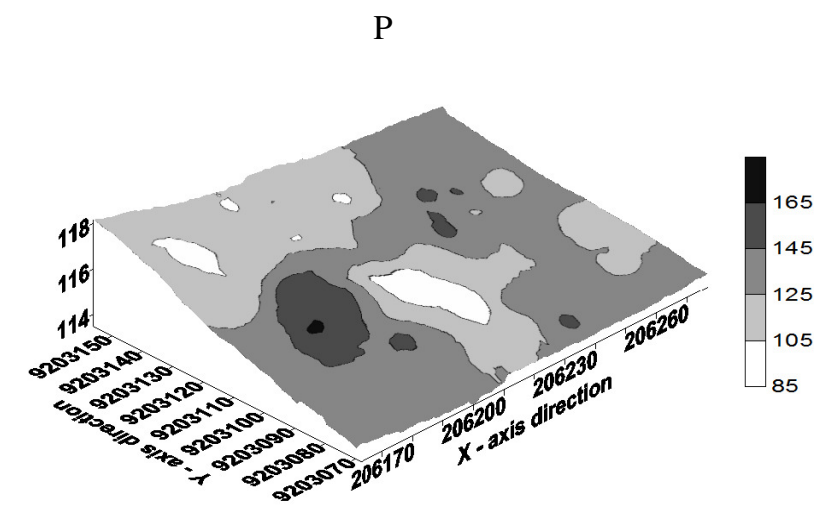

$\mathrm{Al}^{3+}$
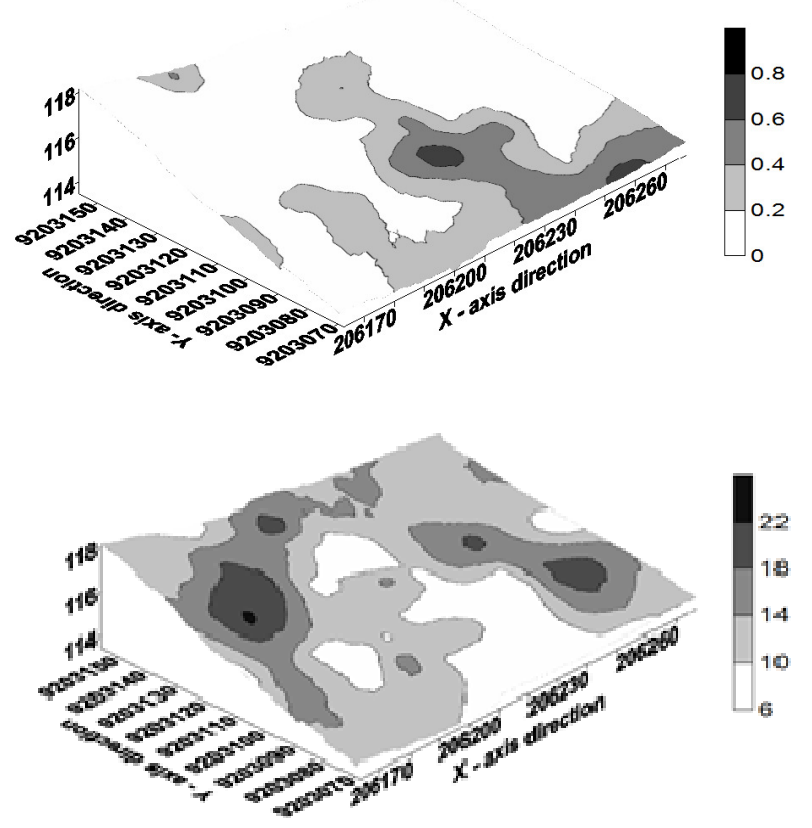

$\%$

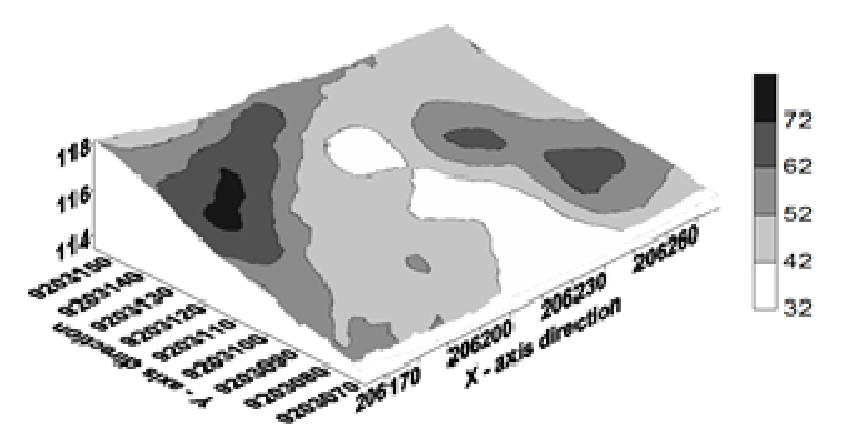

Figure 2. Kriging maps of chemical attributes in Archeological Dark Earths under Cacao cultivation in Western Amazonia. 


\section{CONCLUSIONS}

Geostatistics provided adequate information to understand the spatial distribution of chemical attributes in the Cocoa area. The spherical and exponential model was adjusted for the variables that presented spatial dependence structure. The spatial distribution of chemical attributes in the area showed a strong and moderate degree of spatial dependence.

In the depth (0.0-0.05 m), all variables studied had a strong spatial dependence, except for Sto $\mathrm{C}$ and TOC that did not present spatial dependence. Moderate spatial dependence was observed at depths $(0.05-0.10 \mathrm{~m})$ for $\mathrm{Ca}$ and $\mathrm{Mg}$, CEC and at depth $(0.10-0.20 \mathrm{~m})$ for P, CEC and $\mathrm{V} \%$.
The kriging technique proved to be an important tool in understanding the dynamics of soil chemical attributes evaluated in this study. The spatial variability of chemical attributes should be taken into account in agricultural planning, this information can be used to optimize fertilizer applications, increasing productivity and reducing costs and environmental problems.

\section{ACKNOWLEDGEMENTS}

The authors thank the Fundação de Amparo à Pesquisa do Estado do Amazonas (FAPEAM), Conselho Nacional de Desenvolvimento Científico e Tecnológico(CNPq) and the Coordenação de Aperfeiçoamento de Pessoal de Nível Superior (CAPES).

RESUMO: As Terras Pretas Arqueológicas (TPAs) são solos de fertilidade que notoriamente são superiores à grande maioria dos solos típicos da região amazônica. Assim, o uso das TPAs intensificou-se devido às características químicas apresentadas por esses solos, como a alta concentração de nutrientes (fósforo, cálcio, magnésio). Nesse sentido, o objetivo deste estudo foi avaliar a distribuição espacial dos atributos químicos do solo em uma área de Terra Preta Arqueológica sob cultivo de cacau no município de Apuí (AM). O mapeamento de uma malha de 42 × $88 \mathrm{~m}$, com espaçamento irregular de $6 \times 8 \mathrm{~m}$, totalizando 88 pontos, foi realizado e, em seguida, foram coletadas amostras de solo nas profundidades de $0,0-0,05 ; 0,05-0,10$; (pH, O.C, Sto. C, $(\mathrm{H}+\mathrm{Al}), \mathrm{P}, \mathrm{K}, \mathrm{Ca}, \mathrm{Mg}, \mathrm{SB}, \mathrm{CEC}$ e V\%). Os dados foram analisados por meio de técnicas estatísticas descritivas e geoestatísticas. Os valores médios e medianos foram ajustados aos valores próximos, indicando distribuição normal, enquanto os atributos químicos do solo foram ajustados aos modelos de semivariogramas esféricos e exponenciais. A maioria dos atributos apresentou coeficiente de variação (CV) entre 12,1 e $60 \%$, caracterizada como variabilidade média, as variáveis do estudo apresentaram diferentes faixas e a maioria teve forte dependência espacial. As técnicas geoestatísticas utilizadas permitiram os ajustes dos modelos teóricos que melhor representaram a semivariância experimental, possibilitando a construção de mapas temáticos da distribuição espacial dos valores dos atributos da área estudada.

PALAVRAS-CHAVE: Atributos do solo. Estatística descritiva. Geoestatística. Apuí. Distribuição espacial.

\section{REFERENCES}

ALHO, L. C.; CAMPOS, M. C. C.; SILVA, D. M. P.; MANTOVANELLI, B. C.; SOUZA, Z. M. Variabilidade espacial da estabilidade de agregados e estoque de carbono em Cambissolo e Argissolo. Pesquisa

Agropecuária Tropical, Goiânia. v. 44, n. 3, p. 246-254, 2014. https://doi.org/10.1590/S1983-

40632014000300001

AMADO, T. J. C.; PES, L. Z.; LEMAINSKI, C. L.; SCHENATO, R. B. Atributos químicos e físicos de Latossolos e sua relação com os rendimentos de milho e feijão irrigados. Revista Brasileira de Ciência do Solo, Viçosa. v. 33, n. 4, p. 831-843, 2009. https://doi.org/10.1590/S0100-06832009000400008

AZEVEDO, E. C. Uso da Geoestatística e de recursos de geoprocessamento no diagnóstico da degradação de um solo argiloso sob pastagem no estado de Mato Grosso. 2004. Tese (Doutorado) Faculdade de Engenharia Agrícola Universidade Estadual de Campinas, Campinas. 
CAMBARDELLA, C. A.; MOORMAN, T. B.; NOVAK, J. M.; PARKIN, T. B.; KARLEN, D. L.; TURCO, R. F.; KONOPKA, A. E. Field-scale variability of soil properties in Central Iowa. Soil Science Society of American Journal, Madison. v. 58, n. 5, p. 1501-1511, 1994. https://doi.org/10.2136/sssaj1994.03615995005800050033x

CAMPOS, M. C. C.; MARQUES JUNIOR, J.; PEREIRA, G. T.; FREITAS, E. V. Dependência espacial de atributos químicos em área cultivada com cana-de-açúcar em Pereira Barreto, SP. Ciência Agronômica, Fortaleza. v. 38, n. 4, p. 350-359, 2007.

CAMPOS, M. C. C.; SANTOS, L. A. C.; SILVA, D. M. P.; MANTOVANELLI, B. C.; SOARES, M. D. R. Caracterização física e química de terras pretas arqueológicas e de 314 solos não antropogênicos na região de Manicoré, Amazonas. Agro@mbiente On-line, Boa Vista. v. 6, n. 2, p. 102-109, 2012. https://doi.org/10.18227/1982-8470ragro.v6i2.682

CUNHA, T. J. F.; MADARI, B. E.; BENITES, V. M.; CANELAS, L. P.; NOVOTNY, E. H.; MOUTTA, R. O.; TROMPOWSKY, P.; SANTOS, G. A. Fracionamento químico da matéria orgânica e características de ácidos húmicos de solos com horizonte A antrópico da Amazônia (Terra Preta). Acta Amazônica, Manaus. v. 37, n. 1, p. 91-98, 2007. https://doi.org/10.1590/S0044-59672007000100010

DALCHIAVON, F. C.; CARVALHO, M. P.; ANDREOTTI, M.; MONTANARI, R. Variabilidade espacial de atributos da fertilidade de um Latossolo Vermelho Distroférrico sob Sistema Plantio Direto. Ciência Agronômica, Fortaleza. v. 43, n. 3 p. 453-461, 2012. https://doi.org/10.1590/S1806-66902012000300006

EMBRAPA - Empresa Brasileira de Pesquisa Agropecuária. Centro Nacional de Pesquisa de Solos. Sistema brasileiro de classificação de solos. 3. ed. Brasília: Embrapa, 2013. 353p.

EMBRAPA - Empresa Brasileira De Pesquisa Agropecuária. Centro Nacional de Pesquisa de Solos. Manual de métodos de análise de solo. 2. ed. Rio de Janeiro, 2011. 230p. (Documento 132).

FALCÃO, N. P. S.; BORGES, L. F. Efeito da fertilidade de terra preta de índio da Amazônia Central no estado nutricional e na produtividade do mamão hawaí (Carica papaya L.). Acta Amazônica, Manaus. v. 36, n. 4, p. 401-406, 2006. https://doi.org/10.1590/S0044-59672006000400001

FRASER, J. A, CLEMENT, C. R. Dark earths and manioc cultivation in Central Amazonia: A window on preColumbian agricultural systems?. Boletim do Museu Paraense Emílio Goeldi. Ciências Humanas, Belem. V. 3, n. 2, p. 175-194, 2008. https://doi.org/10.1590/S1981-81222008000200004

GERMAN, L. A. Historical contingencies in the coevolution of environment and livelihood: contributions to the debate on Amazonian Black Earth. Geoderma, Amsterdam. v. 111, n. 3-4, p. 307-331, 2003.

https://doi.org/10.1016/S0016-7061(02)00270-7

GLASER, B.; BALASHOV, E.; HAUMAIER, L.; GUGGENBERGER, G.; ZECH, W. Black carbon in density fractions of anthropogenic soils of the Brazilian Amazon region. Organic Geochemistry, Madison. v. 31, n. 7 8, p. 669-678, 2000. https://doi.org/10.1016/S0146-6380(00)00044-9

GOLDEN SOFTWARE. Surfer for Windows version 8.0. Colorado: Golden, 2002.

GUIMARÃES, W. D.; GRIPP JUNIOR, J.; MARQUES, E. A. G.; SANTOS, N. T.; FERNANDES, R. B. A. Variabilidade espacial de atributos físicos de solos ocupados por pastagens. Ciência Agronômica, Fortaleza. v. 47, n. 2, p. 247-255, 2016.

ISAAKS, E. H.; SRIVASTAVA, R. M. An introduction to applied geoestatistics. New York: Oxford University Press, p. 561, 1989. 
KERN, D. C.; KÄMPF, N. Antigos assentamentos indígenas na formação de solos com Terra Preta Arqueológica na região de Oriximiná, Pará. Revista Brasileira de Ciência do Solo, Viçosa. v. 13, p. 219225.1989 .

KERN, D. C.; KÄMPF, N. Ação antrópica e pedogênese em solos com Terra Preta em CachoeiraPorteira, Belém. Museu Paraense Emílio Goeldi. v. 1, p. 187-201, 2005.

LIMA, J. S. S.; SOUZA, G. S.; SILVA, S. A. Distribuição espacial da matéria orgânica, grau de floculação e argila dispersa em água em área de vegetação natural em regeneração e pastagem. Revista Árvore, Viçosa. v. 37, n. 3, p. 539-546, 2013. https://doi.org/10.1590/S0100-67622013000300017

MANTOVANELLI, B. C.; CAMPOS, M. C. C.; ALHO, L. C.; FRANCISCON, U.; NASCIMENTO, M. F.; SANTOS, L. A. C. Distribuição espacial dos componentes de acidez do solo em área de campo natural na região de Humaitá, Amazonas. Revista de Ciências Agroambientais, Rio Verde. v. 14, n. 1, p. 1-9, 2016. Doi:

MARQUES JÚNIOR, J.; SOUZA, Z. M.; PEREIRA, G. T.; BARBIERE, D. M. Variabilidade espacial de matéria orgânica, P, K e CTC de um Latossolo cultivado com cana-de-açúcar por longo período. Revista de Biologia e Ciência da Terra, Paraíba. v. 8, n. 1, p. 153-152, 2008.

MINITAB RELEASE 14.1. Statistical Software. US/Canada, 2000.

MONTANARI, R.; MARQUES JÚNIOR, J.; PEREIRA, G. T.; SOUZA, Z. M. Forma da paisagem como critério para otimização amostral de Latossolos sob cultivo de cana-de-açúcar. Pesquisa Agropecuária Brasileira, Brasilia. V. 40, n.1, p. 69-77, 2005. https://doi.org/10.1590/S0100-204X2005000100010

NOGUEIRA, M. C. S. Experimentação agronômica I. Piracicaba: Universidade de São Paulo, 2007. 463p.

NOVOTNY, E. H.; AZEVEDO, E. R.; BONAGAMBA, T. J.; CUNHA, T. J. F.; MADARI, B. E.; BENITES, V. M.; HAYES, M. H. B. Studies of the compositions of humic acids from Amazonian dark earth soils. Enviromental Science Technology, Madison. v. 41, n. 2, p. 400-405, 2007. https://doi.org/10.1021/es060941x

OLIVEIRA, I. A.; MARQUES JUNIOR, J.; CAMPOS, M. C. C.; AQUINO, R. E.; FREITAS, L.; SIQUEIRA, D. S.; CUNHA, J. M. Variabilidade Espacial e Densidade Amostral da suscetibilidade Magnética e dos Atributos de Argissolos da Região de Manicoré, AM. Revista Brasileira de Ciência do Solo, Viçosa. v. 39, n. 3, p. 668-681, 2015. https://doi.org/10.1590/01000683rbcs20140496

PESSOA JUNIOR, E. S.; SOUZA, W. B.; SOUZA, K. S.; PIO, M. C. S.; SANTANA, G. P. Terra Preta de Índio na Região Amazônica. Scientia Amazônica, Manaus. v.1, n. 1, p. 1-8, 2012.

ROZANE, D. E.; CENTURION, J. F.; ROMUALDO, L. M.; TANIGUCHI, C. A. K.; TRABUCO, M.; ALVES, A. U. Estoque de carbono e estabilidade de agregados de um Latossolo vermelho distrófico, sob diferentes manejos. Bioscience Journal, Uberlândia. v. 26, n. 1, p. 24-32, 2010.

SANCHEZ, R. B.; MARQUES, J. R. J.; SOUZA, Z. M.; PEREIRA, G. T.; MARTINS FILHO, M. V. Variabilidade espacial de atributos do solo e de fatores de erosão em diferentes pedoformas. Bragantia, Campinas. v. 68, n. 4, p. 1095- 1103, 2009. https://doi.org/10.1590/S0006-87052009000400030

SANTOS, L. A. C.; CAMPOS, M. C. C.; AQUINO, R. E.; BERGAMIN, A. C.; SILVA, D. M. P.; MARQUES JUNIOR, J.; FRANÇA, A. B. C. Caracterização de terras pretas arqueológicas no sul do estado do Amazonas. Revista Brasileira de Ciência do Solo, Viçosa. v. 37, n. 4, p. 1:12, 2013. https://doi.org/10.1590/S010006832013000400001

SILVA NETO, S. P.; SANTOS, A. C.; LEITE, R. L. L.; DIM, V. P.; NEVES NETO, D. N.; SILVA, J. E. C. Variação espacial do teor de matéria orgânica do solo e produção de gramínea em pastagens de capimmarandu. Bioscience Journal, Uberlandia. v. 28, Supl. 1, p. 41-53, 2012. 
SIQUEIRA, D. S.; MARQUES JÚNIOR, J.; PEREIRA, G. T. The use of landforms to predict the variability of soil and orange attributes. Geoderma, Amsterdam. v. 155, n. 2, p. 55-66, 2010.

https://doi.org/10.1016/j.geoderma.2009.11.024

SOIL SURVEY STAFF. Keys to soil taxonomy. 11, ed. Washington: United States Department of Agriculture. Natural Resources Conservation Service. 2010. 338p.

SOUZA, Z. M.; MARQUES JÚNIOR, J.; PEREIRA, G. T.; MOREIRA, L. F. Variabilidade espacial do pH, $\mathrm{Ca}, \mathrm{Mg}$ e V\% do solo em diferentes formas do relevo sob cultivo de cana-de-açúcar. Ciência Rural, Santa Maria. v. 34, n. 6, p. 1763-1771, 2004. https://doi.org/10.1590/S0103-84782004000600015

VIANA, S. F.; CAMPOS, M. C. C.; CUNHA, J. M.; NASCIMENTO, W. B.; MENDONÇA JÚNIOR, A. F. Variabilidade espacial dos atributos químicos em terra preta de índio cultivada na região de Novo Aripuanã, AM. Revista Verde de Agroecologia e Desenvolvimento Sustentável, Pombal. v. 11, n. 3, p. 53-58, 2016. https://doi.org/10.18378/rvads.v11i3.4385

VIEIRA, S. R.; DECHEN, S. C. F.; SIQUEIRA, G. M.; DUFRANC, G. Variabilidade espacial de atributos físicos e químicos relacionados com o estado de agregação de dois Latossolos cultivados no sistema de semeadura direta. Bragantia, Campinas. v. 70, n. 1, p. 185-195, 2011. https://doi.org/10.1590/S000687052011000100025

VIEIRA, S. R.; HATFIELD, T. L.; NIELSEN, D. R.; BIGGAR, J. W. Geostatistical theory and application to variability of some agronomical properties. Hilgardia, California. v. 51, n. 3, p. 1-75, 1983.

https://doi.org/10.3733/hilg.v51n03p075

WARRICK, A. W.; NIELSEN, D. R. Spatial variability of soil physical properties in the field. In: Hillel D. (Ed.). Applications of soil physics. p. 319-344, 1980. https://doi.org/10.1016/B978-0-12-348580-9.50018-3

WELDKAMP, E. Organic Carbon Turnover in Three Tropical Soils under Pasture after Deforestation. Soil Science Society of American Journal, Madison. v. 58, n. 1, p. 175-180, 1994.

https://doi.org/10.2136/sssaj1994.03615995005800010025x

YEOMANS, J. C.; BREMNER, J. M. A rapid and precise method for routine determination of organic carbon in soil. Soil Science Plant Analysis, Madison. v. 19, n. 3, p. 1467-1476, 1988.

https://doi.org/10.1080/00103628809368027

ZANÃO JÚNIOR, L. A.; LANA, R. M. Q.; GUIMARÃES, E. C. Variabilidade espacial do pH, teores de matéria orgânica e micronutrientes em profundidade em um Latossolo Vermelho sob semeadura direta. Ciência Rural, Santa Maria. v. 37, n. 4, p. 1000-1007, 2007. https://doi.org/10.1590/S0103-84782007000400013 